\title{
Was pike on the menu? Exploring the role of freshwater fish in medieval England
}

\author{
Angela Maccarinelli ${ }^{1}$ id
}

Received: 14 December 2020 / Accepted: 8 June 2021 / Published online: 14 July 2021

(c) The Author(s) 2021

\begin{abstract}
Historical sources report that some species of freshwater fish were considered luxury food items in England during the Middle Ages. The high retail price associated with species such as pike, salmon and sturgeon, as well as restrictions of fishing rights on rivers, estuaries and natural and artificial ponds, proves their exclusivity and role as symbols of social privilege. In this work, the zooarchaeological evidence from 11 English sites dated between the 11th and the 15th c. AD is discussed. This paper explores the differences between the ranges of freshwater species recovered from different site types, by looking at specific features that could define these fishes as luxury items: in particular, species selection and fish size are investigated as potentially meaningful variables. The size of fish will be used as an indicator of status and interpreted in view of the increasing phenomenon of fishing from artificial fishponds.
\end{abstract}

Keywords Diet $\cdot$ Status $\cdot$ Fish size $\cdot$ Biometry $\cdot$ Middle Ages $\cdot$ Britain

\section{Introduction}

Many authors describe how typology, variety and quantity of food consumed helped define sociocultural identities in past and present societies (e.g. Twiss 2012; Van der Veen 2003). In zooarchaeology, diet is perhaps one of the most widely discussed topics, contextualising meals of past populations within a type of society, religion or social rank, conferring to food the value of material culture. Part of zooarchaeological research is also devoted to establishing criteria to identify luxury food, to be used as markers of status (e.g. Crabtree 1990; Thomas 1999; Ashby 2002; Ervynck et al. 2003; Grau Sologestoa 2017).

Fish-based meals, in particular, tend to be related to cultural identities and socio-economic status because they often depend on the wealth and religious beliefs of the consumer, even today. These implications of fish consumption were perhaps even stronger in medieval societies, where meals at

This article is part of the Topical Collection on Fishing Over the Millennia

Angela Maccarinelli

angela.maccarinelli@gmail.com

1 Department of Archaeology, University of Sheffield, Sheffield, UK high status tables were impregnated with religious symbolism, rituals and glorification of personal wealth (Klemettilä 2012, 8-14).

In medieval times, everyday eating and drinking followed the seasonal harvests, the dictates of the Church and the medical science of that time; day-to-day consumption marked the social gap between rich and poor consumers, both in terms of quality and quantity of food consumed (Van der Veen 2003, 415). During special occasions, such as religious festivities and political meetings, wealthy hosts would have offered luxurious and opulent banquets, underlining social distinctions and strengthening alliances; however, occasionally, the middle class would have also tried to mimic the upper class, stretching the family resources for a special meal, which would not be representative of the wealth of the household (Ashby 2002). In this setting, freshwater fish can become a useful means in order to emphasise these power plays within medieval society, thanks to its heterogeneous role as luxury and peasant foods (Dyer 1994, 108).

In medieval England, climatic fluctuations, pollution and overexploitation of the freshwater habitat caused modifications of the aquatic ecosystem and a consequent reduction of some species' frequency and size (Hoffman 2008). There are exceptions to this trend, namely eel (Anguilla anguilla), which, because of its excellent physiological adaptability to different environments, was not dramatically affected by 
such modifications (Hoffman 2008). The movement and concentration of people in towns during the 10th c. AD increased the levels of water pollution (and the consequent shrinkage of the freshwater ecosystem) but also the demand for fish; this demand was no longer supported by freshwater supplies (Barrett et al. 2004a).

Despite the high number of freshwater resources in England, access to this type of fish was not equal for all social classes. One of the historical phenomena connected with the arrival of the Normans in 1066 AD was the rise of land privatisation, incorporated into estates, and the growth of private fisheries (Sykes 2007). These changes were aimed at enhancing the visibility and power of the new Norman aristocracy. This increasing regulation of freshwater aquatic sources and the exclusivity of fishing rights dramatically diminished the accessibility to freshwater food, and consequently increased the value of the freshwater catch (Dyer 1994). More investments were also devoted towards the construction of private ponds connected with high status estates. Ponds were first a symbol of royal status, later also becoming features of aristocratic manors and ecclesiastic sites (Locker 2018, 47). Fishponds' function was mostly exclusivity: they provided prestigious meals for special occasions and very rarely produced surplus for sale; river fisheries, on the other hand, were much more productive (Taylor 2000).

Religion also played an important role within this context. Religious precepts dictated the consumption of fish on fast days among all social classes, while for monks, meat was generally forbidden according to the Rule of St. Benedict that stated monks should not consume quadrupeds' meat, except for the sick, old men and children (Patrick 2016). The English Benedictine Reform of the 10th c. AD represented an attempt to give new force to the application of the Rule and this may have triggered a higher demand for fish (Dyer 1994). However, concessions and (mis)interpretations of the rules were the norm (Patrick 2016, 31). We know, indeed, that by the 13th c. $\mathrm{AD}$, the monastic diet was comparable to an upper-class diet, both in terms of quality and quantity of food consumed (Harvey 1993, 34).

As a result of all these processes, freshwater fish became a less significant part of the diet with some species raised to symbols of social privilege (Dyer 1994). However, not all freshwater species had the same value. From historical sources dated to the 11th-15th c. AD, we know that species such as freshwater bream (Abramis brama), pike (Esox lucius), perch (Perca fluviatilis), burbot (Lota lota), sturgeon (Acipenser sp.) and salmon (Salmo sp.) were typically expensive and/or highly valued, while other species, like eel or small Cyprinidae (carps and minnows), were sold cheaply at the market, especially from the 15 th $\mathrm{c}$. AD onwards, and were thus also available to the lower classes (Dyer 1994; Woolgar 2000). Furthermore, larger and selected specimens (e.g. large pike, "luce," or large eel, "grete" eel), or restricted and rare species (e.g. sturgeon), were typically destined to high status groups, featuring on the table as a sign of wealth (Woolgar 2016, 172).

Prolific zooarchaeological research on medieval fish consumption, focussed on the typology and status of sites, has been performed in central Europe (e.g. Heinrich 1994; Galik and Kunst 2004; Borvon 2019), especially in Belgium (e.g. Van Neer and Ervynck 1994, 2004; Ervynck 1997; Pigiére et al. 2004; Van Neer et al. 2009). A number of zooarchaeological reviews for medieval England include fish remains, approached as a comparison of marine/freshwater/migratory fish frequencies (e.g. Barrett et al. 2004a; Serjeantson and Woolgar 2006; Harland et al. 2016; Holmes 2017; Albarella 2019). Specific work has been undertaken on marine fish (e.g. Locker 2000; Barrett et al. 2004b; Barrett and Orton 2016), but very little has been published specifically on freshwater fish (Locker 2018).

These studies proved how, in England, fish assemblages show a decrease in freshwater and migratory species in favour of marine species at around $1000 \mathrm{AD}$, during the so-called fish event horizon (Barrett et al. 2004a). Consequently, from the 11th c. AD onwards, herring (Clupea harengus) and cod (Gadus morhua), and successively other Gadiformes, became the most common species consumed, especially as a preserved product, representing a form of cheap staple food.

A number of English assemblages connected with wealthy contexts showed the preferential consumption of highly regarded fish species (e.g. the later 15th-16th c. AD assemblage from the rural high status manor of Little Pickle (Bullock 1994); or the mid-11th c. AD assemblage from Westminster Abbey, (Locker 1995)); however, the definition of clear status indicators has been hampered by the scarcity of freshwater fish remains for the period, which often prevent reliable comparisons among sites. This overall shortage of data is reflected in the scarcity of work on the biometric analysis on freshwater fish; traditional biometric approaches, like the use of regression equations for fish size reconstruction (e.g. Libois and Libois 1988 on Cypriniformes), are based on a limited number of measurements, which are typically reflected in small data samples.

This paper aims to fill this information gap by exploring the link between freshwater fish and wealthy households in medieval England, from the Norman Conquest until the start of the Early Modern Period (11th to 15th c. AD). The use of log ratio scaling technique within biometric analysis allows an increase in the sample size and the possibility to approach the recognition of status indicators from a different angle. Specifically, we will try to tackle the following issues:

1. How is the consumption of freshwater and marine fish interrelated and linked with the status of the sites analysed? 
Fig. 1 Geographic location of sites discussed in this research. For site names, see reference number (map ref. $\mathrm{n}$ ) in Table 1

2. How are species and size related with the economic and social value of freshwater fish and the tenure of private freshwater sources (i.e. river fisheries and fishponds)?

3. What is the potential of biometry for exploring status markers within this context?

\section{Material and methods}

For this analysis, 11 fish assemblages were re-studied by the author (following a consistent recording system and approach) and selected on the basis of the type of site, chronology and availability of the material. These assemblages, dated between the 11th and the 15th c. AD, are representative of both high status and low status, secular and religious and inland and coastal areas across England, although some areas are underrepresented in this study, e.g. the southwest and north (Fig. 1). The two castles and Eynsham Abbey are regarded to be of the highest status in the sample, followed by St. Mary Graces and St. Gregory's Priory (the latter possibly being less wealthy). Urban assemblages can be representative of various status conditions, but, on average, they tend to be less wealthy than other sites discussed. Table 1 and Online Resource 1 summarise all relevant information related to the sites. 
Table 1 List of sites considered

\begin{tabular}{|c|c|c|c|c|c|c|c|c|c|c|c|}
\hline \multirow[t]{2}{*}{ Site } & \multirow[t]{2}{*}{ Map ref. $n$} & \multirow{2}{*}{ Useful chronology } & \multirow[t]{2}{*}{ Type } & \multirow[t]{2}{*}{ County } & \multicolumn{6}{|c|}{ Recovery } & \multirow[t]{2}{*}{ Tot NISP } \\
\hline & & & & & FS & $\mathrm{CS}$ & $\mathrm{S}$ & $\mathrm{H}-\mathrm{C}$ & MIX & $\mathrm{ND}$ & \\
\hline Stafford Castle & 1 & 11 th-15th $\mathrm{c}$ & Secular castle & Staffordshire & & & $\mathrm{X}$ & $\mathrm{X}$ & & & 5171 \\
\hline Windsor Castle & 2 & 11 th-14th c & Secular castle & Berkshire & $\mathrm{X}$ & $\mathrm{X}$ & & $\mathrm{X}$ & & & 12,681 \\
\hline Eynsham Abbey & 3 & 11 th-15th c & Religious & Oxfordshire & $X$ & $\mathrm{X}$ & $\mathrm{X}$ & $\mathrm{X}$ & & & 9026 \\
\hline St. Mary Graces & 4 & 15 th $\mathrm{c}$ & Religious & London & & & & & $\mathrm{X}$ & & 979 \\
\hline St. Gregory's Priory & 5 & 14th-15th c & Religious & Kent & $\mathrm{X}$ & & & & & & 9356 \\
\hline Stert Street $(38,40,42,44)$ & 6 & 13th-15th c & Urban & Oxfordshire & & $\mathrm{X}$ & & $\mathrm{X}$ & & & 2214 \\
\hline Orchard Lane & 7 & 11 th-12th c & Urban & Cambridgeshire & $\mathrm{X}$ & & & & & & 196 \\
\hline Fleet Valley & 8 & 12 th-15th $\mathrm{c}$ & Urban & London & $X$ & $\mathrm{X}$ & & $X$ & & & 1369 \\
\hline Trig Lane & 9 & 13th-15th c & Urban & London & $X$ & & & & $X$ & & 208 \\
\hline Billingsgate & 10 & 11 th-15th c & Urban & London & & & & & & $\mathrm{X}$ & 2233 \\
\hline Milk Street & 11 & 11 th-14th c & Urban & London & & & $X$ & & $X$ & & 1492 \\
\hline
\end{tabular}

Recovery $=F S$ fine-sieved with mesh $\leq 2 \mathrm{~mm} ; C S$ coarse-sieved, with mesh $>2 \mathrm{~mm} ; S$ sieved, with no indication of mesh size; $H$ - $C$ hand-collected; MIX sieved and hand-collected, mixed after collection; $N D$ no information about recovery methods is available.

This paper focuses on two types of ichthyoarchaeological evidence: taxonomic frequencies and biometry. Percentages are calculated based on the total NISP (Number of Identified Specimens) for all graphs. ${ }^{1}$ A threshold of NISP larger or equal to 100 was implemented, and, for smaller assemblages (e.g. Orchard Lane), interpretations and generalisations were limited.

The recording protocol follows Maccarinelli (in prep; Online Resource 2). Identification of fish skeletal remains relied mostly on comparison with modern specimens of the zooarchaeological reference collection held at the University of Sheffield (UK) and the Royal Belgian Institute of Natural Sciences, Brussels (Belgium), but a number of other resources were also used (Online Resource 2).

Measurements for pike, perch, Cyprinidae and eel from different elements (Online Resource 2) were combined through the use of the log ratio scaling technique; this method calculates the decimal logarithm of the ratio between each measurement and its standard (Simpson et al. 1960; Meadow 1999, 288) allowing measurements from different elements to be combined. This technique increases the sample size available and is widely used in zooarchaeological analyses (Meadow 1999; Albarella and Payne 2005). A sample size threshold by phase of $\geq 40$ measurements was applied.

\section{Results}

Analyses were done by groups of sites, arranged by typology as indicated by Table 1 . As the focus of the interpretation is on status, it was decided to combine material by chronology

\footnotetext{
${ }^{1}$ Percentages were also calculated as the average of the percentages for each site, but the results did not change significantly; thus, these results are not shown here.
}

and recovery methods (possible consequent biases will be discussed where relevant).

\section{Taxonomic frequencies (NISP)}

The results show the consumption of freshwater fish was overall more frequent in the higher status sites (Figs. 2 and 3). At Windsor, freshwater fish was fewer compared to Stafford; however, at Windsor Castle, 40 fish taxa were identified, mostly marine but with a higher number of freshwater taxa compared to the other 10 sites (Table 2). A large taxonomic diversity would signify a limitless accessibility to species, achievable only within wealthier contexts; yet a factor to consider is that not all freshwater species retrieved may necessarily represent edible food or specifically targeted species (i.e. representing an accidental catch or gut content of larger predators such as pike). Inequity in the number of freshwater and marine taxa is less pronounced at castle sites, but typical of many other sites (and in favour of marine species) (Figs. 4 and 5). Species diversity is highly dependent on the size of the assemblage and on the recovery methods used (Ashby 2002); however, despite the small sample size, urban assemblages are represented by a relatively large range of marine taxa, strengthening the significance of freshwater taxa paucity.

Collectively, freshwater fish were consumed more frequently in towns than in religious establishments, but not when considering Eynsham Abbey and St. Mary Graces specifically. Conversely, St. Gregory's Priory has lower freshwater fish frequencies and this may be representative of the lowest wealth but also of the position near the coast with easier access to marine fish.

Within towns, we observe a lower frequency and taxonomic diversity of freshwater fish and the highest proportion 


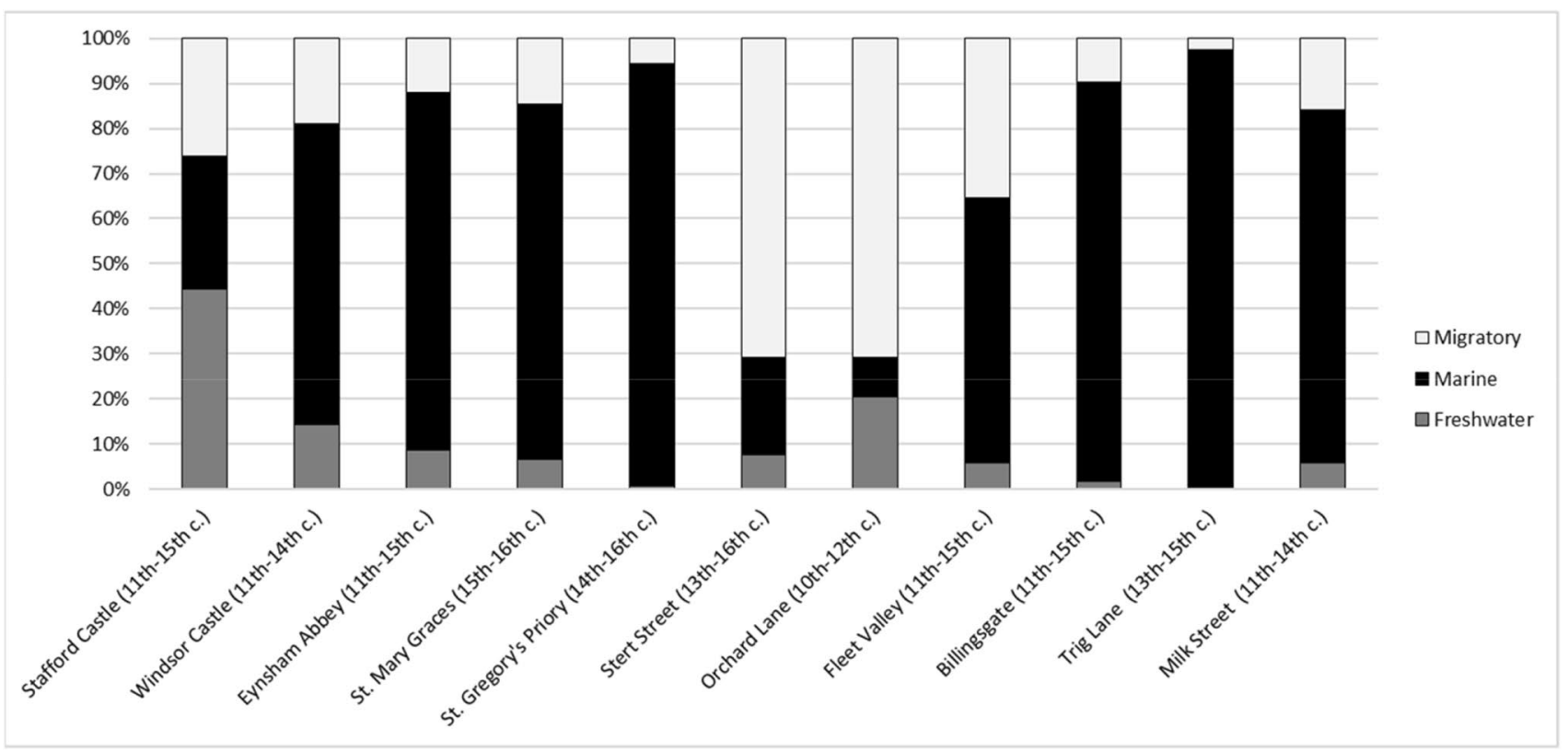

Fig. 2 Frequencies (NISP) of environmental distribution for all sites

of migratory taxa (mostly eel). Among London sites, the high diversity of marine taxa can be linked to their wide availability at the city's markets. The high occurrence of freshwater taxa at Orchard Lane and, to a lesser extent, at Stert Street can be partly representative of their location inland and near rivers (and near the Fens in the case of Orchard Lane). The small Orchard Lane assemblage is likely affected by recovery bias (only fine-sieved small remains from a single context were recovered) but a major reliance on the local river is visible, mostly exploited for eel and, in a lower proportion, for Cyprinidae; these were mostly interpreted as by-catch due to their small size (Smith 1997). Similar high frequencies of eel were recorded for Stert Street.

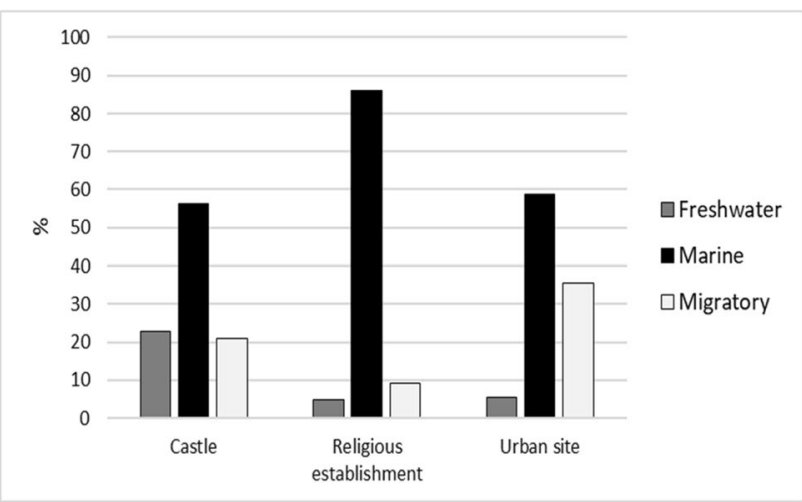

Fig. 3 Frequencies (NISP) of environmental distribution by typology of sites
Pike is well represented only at Stafford Castle, followed by Eynsham Abbey and St. Mary Graces (Fig. 6). Collectively, pike appears to be more abundant at castles, followed by religious establishments and, ultimately, urban sites (Fig. 7). If the coastal St. Gregory's Priory is disregarded, pike frequency nearly doubles within ecclesiastic establishments.

The royal sturgeon (Acipenser sturio/Acipenser oxyrinchus) was found at Windsor Castle and Eynsham Abbey. It was also present in three London urban sites (Billingsgate, Trig Lane and Fleet Valley (Locker 1994)).

Salmonidae were more commonly consumed at the two castle sites (Fig. 8). This fish family has a very delicate skeleton, strongly affected by taphonomic processes, but it is also ecologically very demanding in terms of water quality; thus, location of the site may again have a big influence in their distribution.

Similarly, burbot was uncommon among the studied assemblages and found mostly within religious establishments (Fig. 9). Burbot was present in the three highest status sites and at St. Mary Graces, while it occurred only at the urban site of Stert Street. The remains of burbot found at Windsor Castle suggest that the species may be present in the Thames (if not imported) and, in this case, the absence of burbot from the London sites may indicate that it was not typically purchased at the market (possibly because of its rarity and high value/price). It is worth mentioning that the skeletal morphology of burbot is not easily distinguishable from small Gadidae; thus, a generic scarcity of burbot may also be due to the identification of its bones to a higher taxonomic level (Gadiformes). 


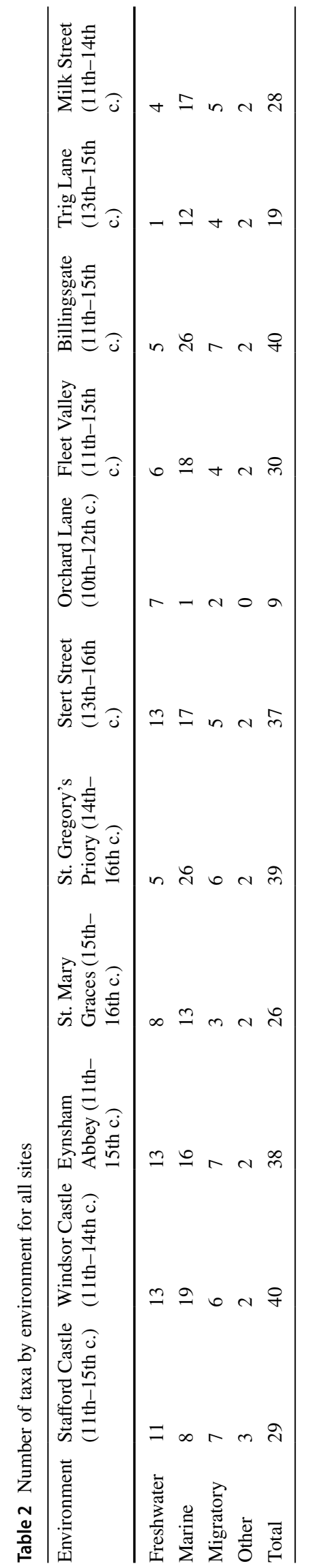

Cyprinidae are the most common freshwater fish at all sites, with the exception of Stafford Castle and Eynsham Abbey, where pike dominates. Pike is also predominant at Trig Lane, but this is likely to be the consequence of a lack of sieving. Cyprinidae are most abundant in castles (particularly Stafford), followed by urban sites and religious establishments (Figs. 10, 11). For the two castles, the high frequency of Cyprinidae may be associated with the presence of ponds; this does not seem to apply for Eynsham Abbey. At St. Mary Graces, the abundance of Cyprinidae could be linked to the presence of water mills, where Cyprinidae were likely fished alongside eels. Among urban sites, the highest number of Cyprinidae remains is found at Orchard Lane, where eel was also abundant, thus probably they were sourced together.

Perch is less regularly recorded than other typical pond fish (i.e. pike and Cyprinidae) and it appears to be more frequently consumed in castles, followed by religious establishments and urban sites (Fig. 9).

Eel appears to be more common at urban sites, where similar percentages of herring are present (Fig. 7), while the smallest frequency of eel is found at religious establishments, where it is offset by the highest presence of herring.

At Windsor Castle material recovered from selected contexts, mostly from better dated kitchen layers of the Round Tower (Site 431), it shows an increase in the frequencies of marine taxa from the 12th c. AD onwards (Fig. 12). This increase is clearly perceivable with the intensification of the presence of herring and, in smaller quantity, also cod, to the detriment of migratory and freshwater fish, especially eel and pike, but also Salmonidae, perch, burbot and Cyprinidae (Figs. 13, 14, 15 and 16).

\section{Biometric analysis}

The largest pikes appear to be recovered from castles (Fig. 17). The greater variation of measurements for pike in castles and in religious establishments suggests a regular supply of pike throughout the year, possibly connected with the management of freshwater sources. Within fishponds, fish could be grown to an optimal or desired weight before culling, resulting in a larger average size. The largest pikes would be fished in rivers, as they tend to be unmanageable in fishponds (Bonow et al. 2016). The distribution of measurements through discrete peaks of size abundance in urban sites could indicate that fishing for pike was undertaken sporadically/seasonally, however this distribution may also be biased by the smaller size of the sample.

Very large pike specimens, with a total length of $1 \mathrm{~m}$ or more, were recovered from the three higher status sites. A few large pikes were also identified in urban contexts; these specimens are likely to represent meals of wealthier dwellers of the city, which were granted fishing rights, or they were 


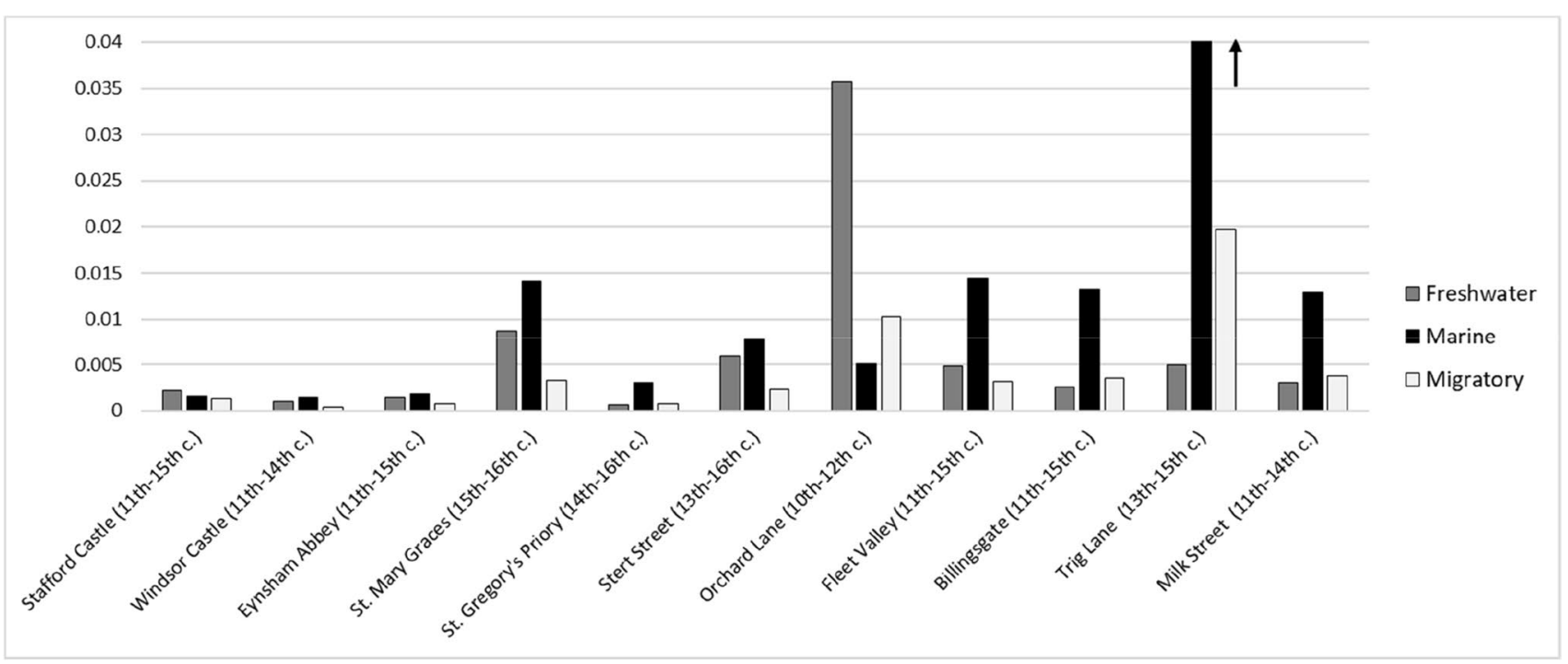

Fig. 4 Environmental index (n of taxa/tot NISP) for all sites

gifts from the rural aristocracy in exchange for favours or loyalty.

At Windsor Castle, the distribution of pike measurements tends to be diverse, but with a focus on adult individuals (Fig. 18). Approaching the 14th c. AD, the distribution of pike sizes, with the exception of some outliers, seems to become bimodal, possibly representing seasonal exploitation or the use of different sources (i.e. river fisheries and fishponds). Despite not showing a significant size change from the better represented 12 th and 14th c. AD samples, the size of pike at Windsor Castle appears to be for each period represented larger than in religious and urban sites.

Biometric analysis for Cyprinidae shows that the largest specimens were consumed at castles, followed by religious establishments, and then urban sites (Fig. 19). In a similar manner to pike, the roughly unimodal distribution of measurements of Cyprinidae from the two castles, together with the wide range of sizes represented, may indicate managed

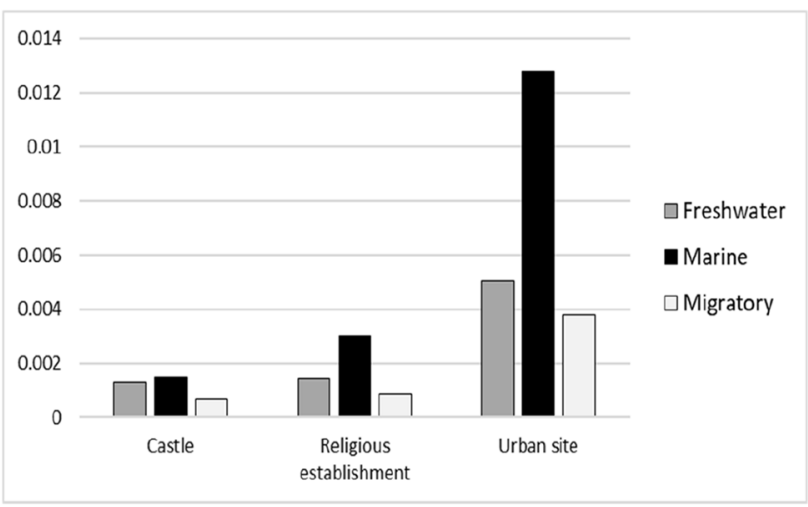

Fig. 5 Environmental index ( $\mathrm{n}$ of taxa/tot NISP) by typology of sites fishing occurring all year round, namely that the fish were kept in fishponds. It is worth mentioning that a great diversity of Cyprinidae sizes would also be representative of species diversity. The smallest specimens were probably a by-catch from river fisheries and water mills or from the stomach content of large predators (e.g. pike). With a smaller average value but a similar distribution and range of sizes, Cyprinidae recovered from religious establishments could also be associated with fishponds. The presence of very large specimens (at Eynsham Abbey) may support the idea of the growth of Cyprinidae within fishponds, as this tempting prey would probably not survive long in natural environments. As with castles, Cyprinidae at religious sites were also caught from river fisheries and water mills, in particular the smallest individuals as by-catch. Indeed, in the specific case of Eynsham Abbey, it was suggested that most of the fishponds were dedicated to the breeding of pike and eel (Ayres et al. 2003) rather than to the growth of Cyprinidae. In urban sites, the heterogeneous distribution of Cyprinidae sizes could possibly be related to less organised fishing (e.g. occasional and/or from different sources) and accidental catches for the smallest specimens.

Similarly, despite the small sample, it seems that larger perches are found at castles, followed by religious establishments (Fig. 20), and only few small perch bones were measured for urban sites. The wide range of measurements from castles may once again be linked with managed fishing, but this trend is not evident in religious establishments.

Despite the higher frequency of eel at urban sites, the largest eels are found at the three highest status sites (Stafford Castle, Eynsham Abbey and Windsor Castle), while the smallest are from the other two religious establishments (St. Mary Graces and St. Gregory's). At St. 


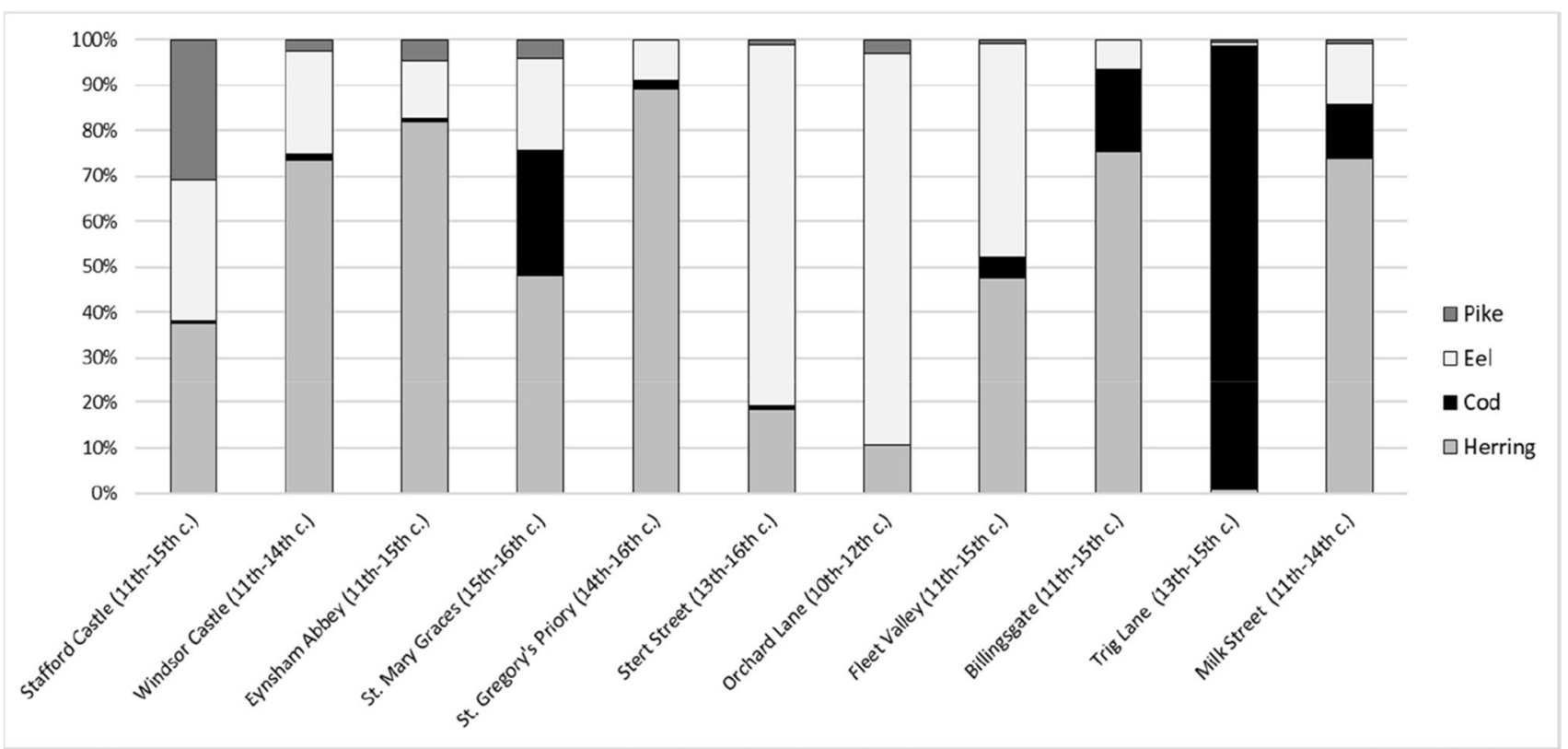

Fig. 6 Distribution of frequencies (NISP) for pike versus three key species (herring/cod/eel) for all sites

Gregory's, the small average size of eel can probably be explained by fishing occurring in estuaries and coastal areas, where younger eels typically live (Tesch 2003). In the wealthier sites, eels were probably purposefully fattened for special occasions, while the largest specimens from towns may again represent gifts from the elite or the meals of richer urban dwellers. The unimodal distribution of eel size on a wide range of measurements for castles (Fig. 21) again suggests a managed catch, possibly throughout the year. The bimodal distribution from religious establishments, represented mostly by Eynsham Abbey's eel, may be connected with the exploitation of different sources (e.g. fishponds, river fisheries or mills), but other reasons could explain the pattern (e.g. sexual

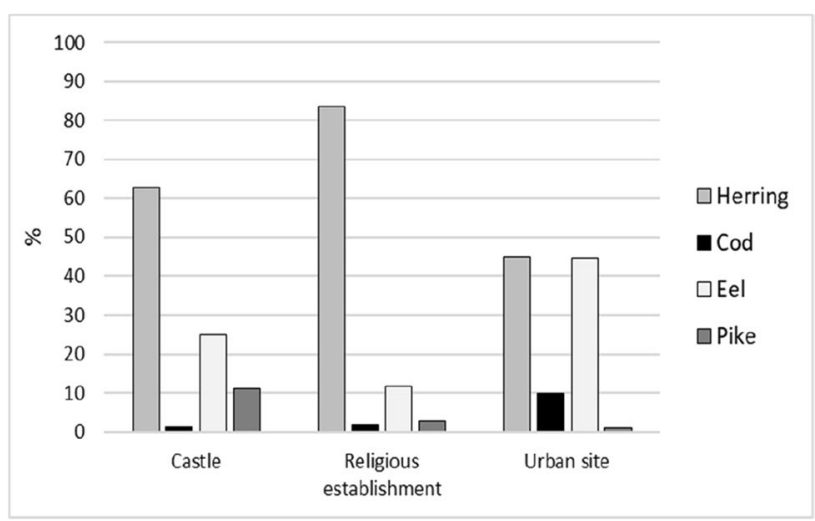

Fig. 7 Distribution of frequencies (NISP) for pike versus three key species (herring/cod/eel) by typology of sites dimorphism). Size distribution for eel from urban sites seems to represent a fishery more focussed on smaller specimens compared to the other site types.

\section{Discussion}

A number of trends have been highlighted from this research characterising high status sites; however, it is important not to oversimplify the evidence. It appears that a high frequency of key freshwater species, in particular pike, perch and Cyprinidae, combined with their large average large sizes could represent an indicator of status within the studied sites. Furthermore, size distribution on

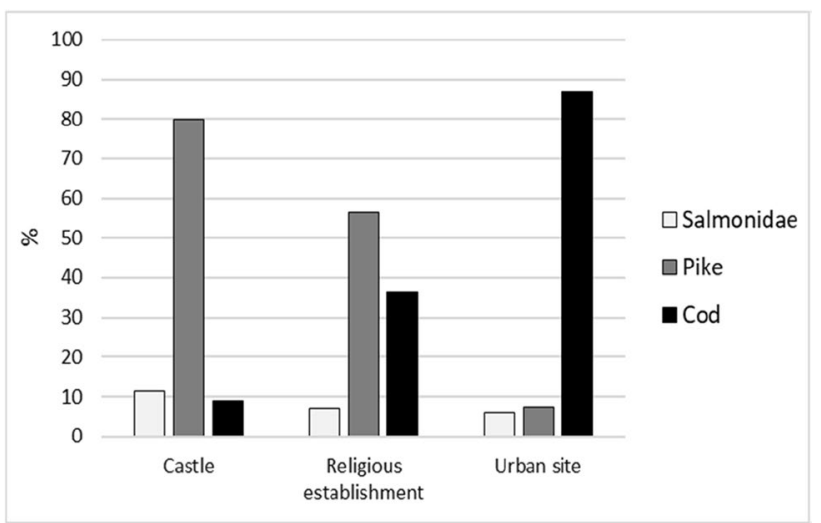

Fig. 8 Distribution of frequencies (NISP) for Salmonidae/pike/cod by typology of sites 


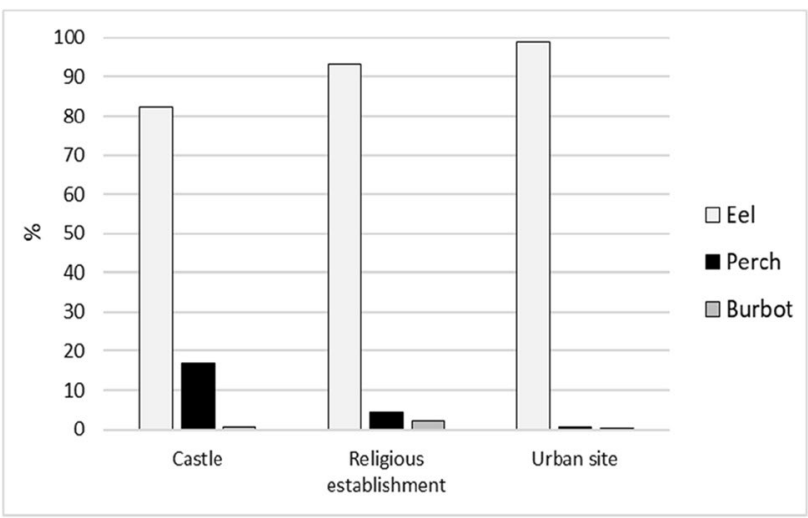

Fig. 9 Distribution of frequencies (NISP) for burbot/perch/eel by typology of site

a wide range of measurements, and generally comparable to a unimodal distribution, appears to represent managed fishing throughout the year, possibly connected with the use of fishponds, and thus with the high status of the sites. Conversely, the occasional occurrence of rare and highly prized species (e.g. sturgeon, Salmonidae, burbot) used as indicators of status appears problematic, at least when analysed in isolation. As observed by others (e.g. Ashby 2002), the presence of prestigious animals in assemblages does not automatically boost the status of the site, as they may represent an occasional meal or a poached catch.

Overall, with the exception of Stafford Castle, the results seem to confirm the general scarcity of freshwater fish already observed by others (e.g. Barrett et al. 2004a; Locker
2018), balanced by a higher incidence of marine species. As exemplified by the case of Windsor Castle, the increased reliance on marine resources from the 11th c. AD onwards (e.g. Barrett et al. 2004a) is a generalised phenomenon within the sites observed, so as a higher degree of control of freshwater resources from the elite and royal court (Bonow et al. 2016).

The link between high status diet and freshwater fish appeared in the form of a higher frequency of freshwater fish and specific species that are known to have been especially prized from castle sites. A similar situation was reported in a review of medieval and post-medieval fish assemblages from Belgian sites (Van Neer and Ervynck 1994), where at Londerzeel castle (later 13th-14th c. AD), the relative proportion of marine species (57\%) was only slightly higher than that of freshwater and migratory species (43\%), among which sturgeon was recorded in large quantities; on the contrary, urban assemblages, dated 13 th-18th c. AD, were dominated by higher proportions of marine fish, especially Gadiformes, Pleuronectiformes and herring. Within our sites, one reason behind the lower frequency of freshwater fish at Windsor Castle, compared to Stafford, could be the location of Windsor near London, which could have facilitated access to marine fish at the city's markets, making the fish diet more diverse than if it was based solely on local resources. The case of Launceston Castle (Smith 1995) represents a similar case; its location near the coast was reflected in a high taxonomic variety of marine species, which were considered to be representative of high status.

Pike's and perch's higher frequencies at higher status sites suggest a connection with the tenure of private freshwater

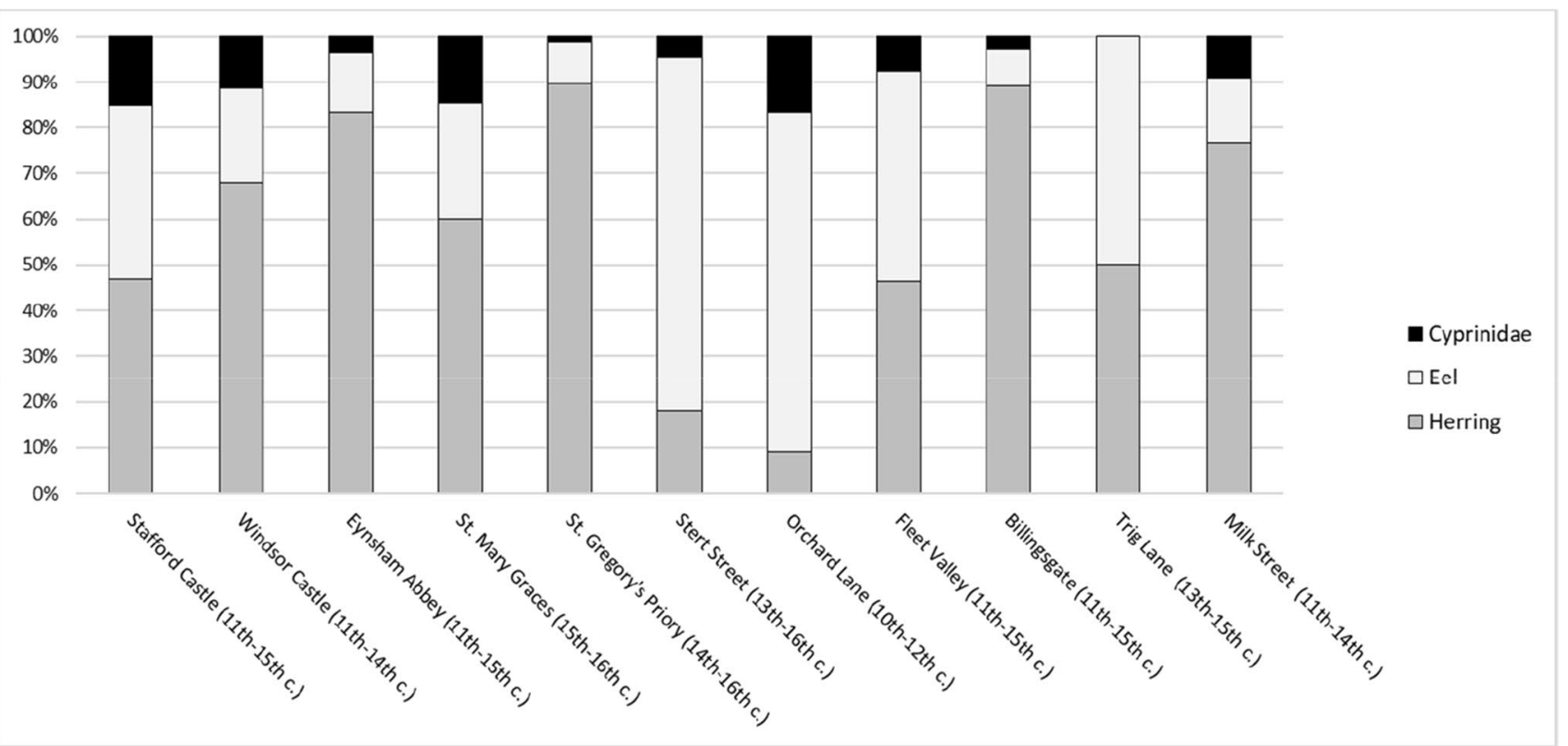

Fig. 10 Distribution of frequencies (NISP) for Cyprinidae versus two key species (eel/herring) for all sites 


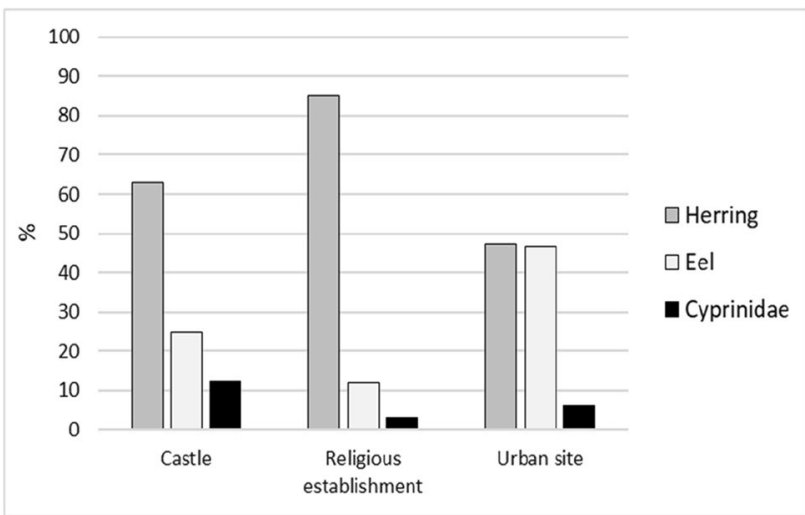

Fig. 11 Distribution of frequencies (NISP) for Cyprinidae versus two key species (eel/herring) by typology of sites

sources (e.g. river fisheries, fishponds, water mills). The low yield of fishponds would not have fulfilled the yearly demand for fish in larger establishments (Currie 1988), which was probably largely supported by riverine fisheries (Bond 2016, 162); however, from an archaeological perspective, the frequency of pike and perch remains would surely be boosted by the presence of fishponds. Pikes recovered within urban contexts are not an oddity, as historical sources tell us that small pikes ("pickerels") were available at the market (Dyer 1994).

Specific habitat requirements of sturgeon and its increasing scarcity, especially after the 12th c. AD (Hoffman 2008), suggest that the geographical location of the site might have an important role in the distribution of the taxon, which from the results appears to be present in the river Thames. As already mentioned, sturgeon recovered within urban contexts

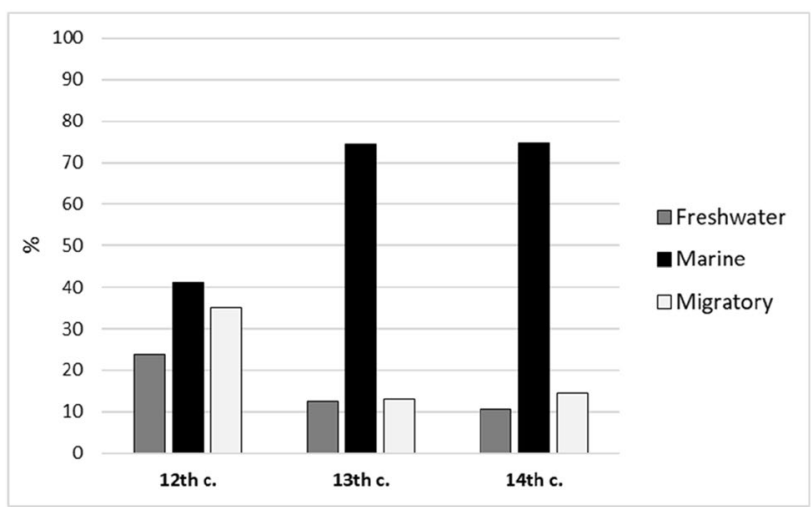

Fig. 12 Frequencies (NISP) of environmental distribution by chronology (12th c., NISP: 1822, FS and CS material; 13th c., NISP: 651, FS, CS and H-C material; 14th c., NISP: 9196, FS, CS and H-C material), all recovery methods from the Round Tower (Site 431), Windsor Castle

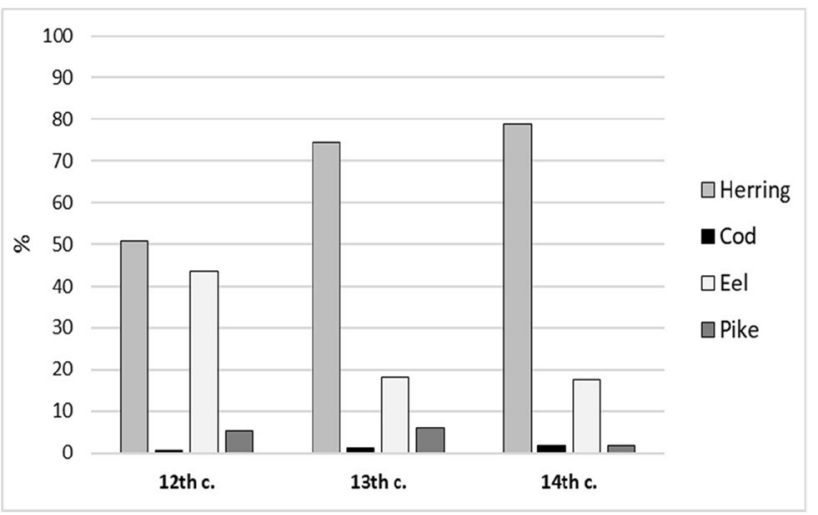

Fig. 13 Distribution of frequencies for pike versus three key species (herring/cod/eel) by chronology (12th c., NISP: 1402, FS and CS material; 13th c., NISP: 420, FS, CS and H-C material; 14th c., NISP: 7341, FS, CS and H-C material), all recovery methods from the Round Tower (Site 431), Windsor Castle

could be part of the mechanisms of exchange of rare, exotic (e.g. carp, peacock) or local wild animals (e.g. deer) among the wealthy members of English medieval society (Albarella 2007).

Zooarchaeological evidence shows how Salmonidae use to be rare in medieval England (Serjeantson and Woolgar 2006); this trend is also confirmed in the 11 sites analysed here. Similarly, the scarcity of burbot reflects a wider phenomenon for the period, as species very susceptible to water pollution became rarer in conjunction with the increasing urbanisation of medieval towns (O'Connor 1989).

Even when we consider species with a dual perception, acquiring value either because of their large size (eel) or reared in ponds (Cyprinidae), assemblages from castles fulfil

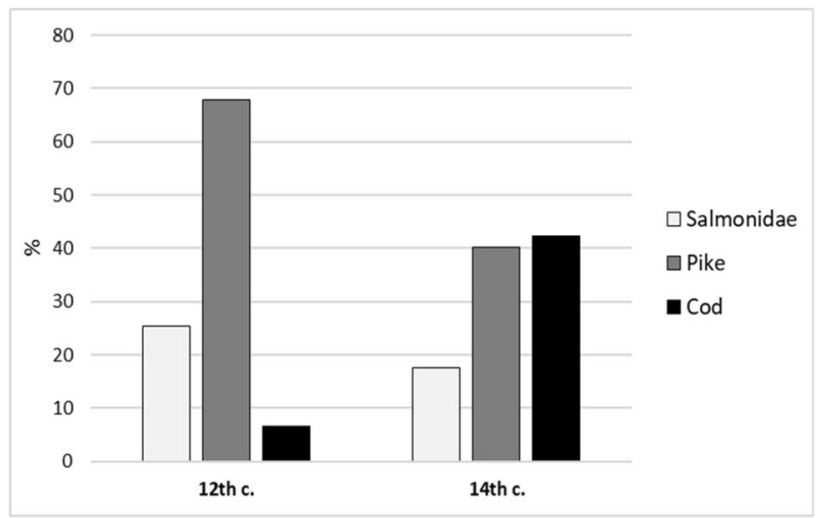

Fig. 14 Distribution of frequencies for Salmonidae/pike/cod by chronology (12th c., NISP: 106, FS and CS material; 14th c., NISP: 329, FS, CS and H-C material), all recovery methods from the Round Tower (Site 431), Windsor Castle 


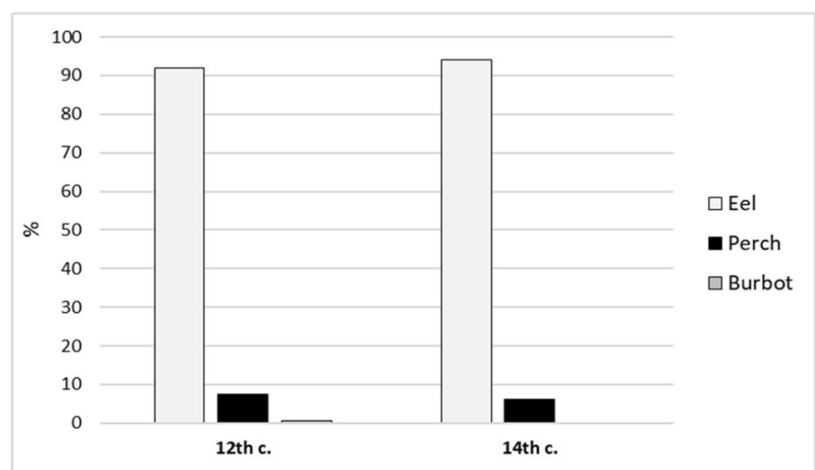

Fig. 15 Distribution of frequencies for burbot/perch/eel by chronology (12th c., NISP: 667, FS and CS material; 14th c., NISP: 1358, FS, CS and H-C material), all recovery methods from the Round Tower (Site 431), Windsor Castle

the expectations of high status consumption. Previous zooarchaeological reviews (Serjeantson and Woolgar 2006) show the presence of Cyprinidae in different site types as typically the most abundant taxa among other primary division freshwater taxa (i.e. excluding eel) and the results generally appear confirm the trend.

All fish taxa tend also to be larger in assemblages recovered from castles. Since large freshwater species were used as displays of wealth rather than primarily for their nutritional value, fish were deliberately left to grow in fishponds. Furthermore, castles probably had access to fresh fish throughout the year, as demonstrated by the wide size range we see for many species (presumably linked to seasonal variation). Fishing that operated on a non-seasonal basis would more likely be represented by individuals of

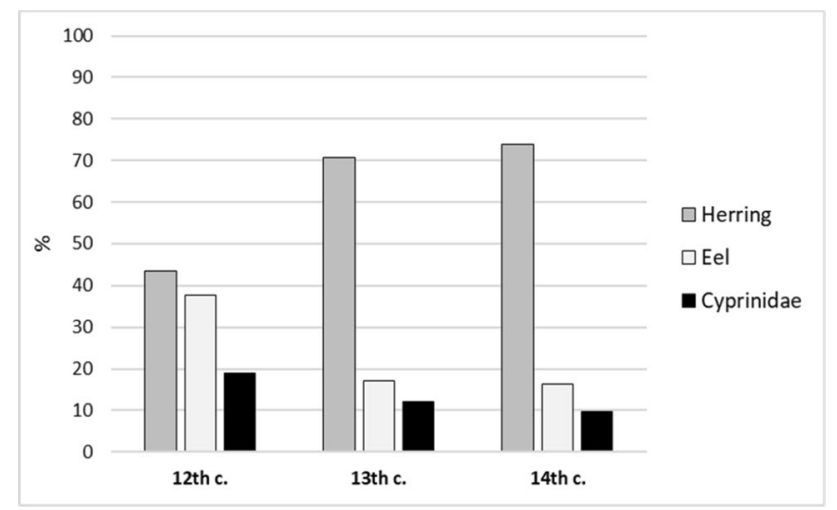

Fig. 16 Distribution of frequencies for Cyprinidae versus two key species (eel/herring) by chronology (12th c., NISP: 1630, FS and CS material; 13th c., NISP: 443, FS, CS and H-C material; 14th c., NISP: 7831, FS, CS and H-C material), all recovery methods from the Round Tower (Site 431), Windsor Castle the same species of many different sizes (with continuous variability) as opposed to seasonal fishing that would result in discrete groups of different sizes (Morales-Muñiz 2014, 3654). This pattern would reflect availability of different freshwater resources and/or artificial environments where the fish were available throughout the year.

The analysis of different consumption patterns in the city of Namur (Belgium) during the 11th-15th c. AD showed a similar trend. Assemblages from the high status castle of Des Comtes, inhabited by both laic and religious folks, and middle-class houses at Grognon (Pigiére et al. 2004) showed how freshwater species predominated in both contexts (mainly Cyprinidae). Nonetheless, a higher proportion of perch was detected for the castle, alongside sturgeon and carp; these latter two species were completely absent in Grognon. The higher status of the castle was represented not only by the presence and greater incidence of higher quality freshwater species, but also by a wider taxonomic spectrum (including long-distance traded marine species) and the larger size of freshwater and migratory fish. Pike, perch and Salmonidae were consistently larger at the castle. Within Grognon, the middle-class occupants were consuming mostly smaller and lower quality freshwater species, together with herring.

Zooarchaeological evidence for religious establishments has provided an insight into wealthy diets at ecclesiastical sites. For instance, the fish assemblage from Westminster Abbey (Locker 1995) shows a diet characterised by a wide variety of species including expensive ones (e.g. sturgeon, Salmonidae and pike). A similar trend has also been detected in medieval France; at the Andlau Abbey (Alsace), for example, the higher frequency of pike recovered from 10 to 12th $\mathrm{c}$. AD deposits, together with other prestigious species such as sturgeon and possibly lamprey (Petromyzontidae), was interpreted as an indicator of the wealth of the monks (Borvon 2019). At the St. Salvadors Benedectine Abbey in Belgium (Ervynck 1997), fish remains from a kitchen deposit dated to the 16th c. AD included a relatively wide variety of species. The diet included preserved marine fish (salted herring and stockfish), but was based predominantly on freshwater catches, mostly eel and carp. Expensive species were also identified, including sturgeon and turbot (Scophthalmus maximus). Ervynck interpreted the consumption of such a wide variety of species as an attempt to escape the monotony of a diet regimented by religious rules and fasting. The evidence of high status from our three religious establishments is less straightforward, probably reflecting the interplay of various potentially conflicting factors. Nonetheless, highly regarded species tend to be more frequent than in urban sites (except for Cyprinidae) and specimens also tend to be larger (except for pike). The relatively smaller sizes of fish from the 


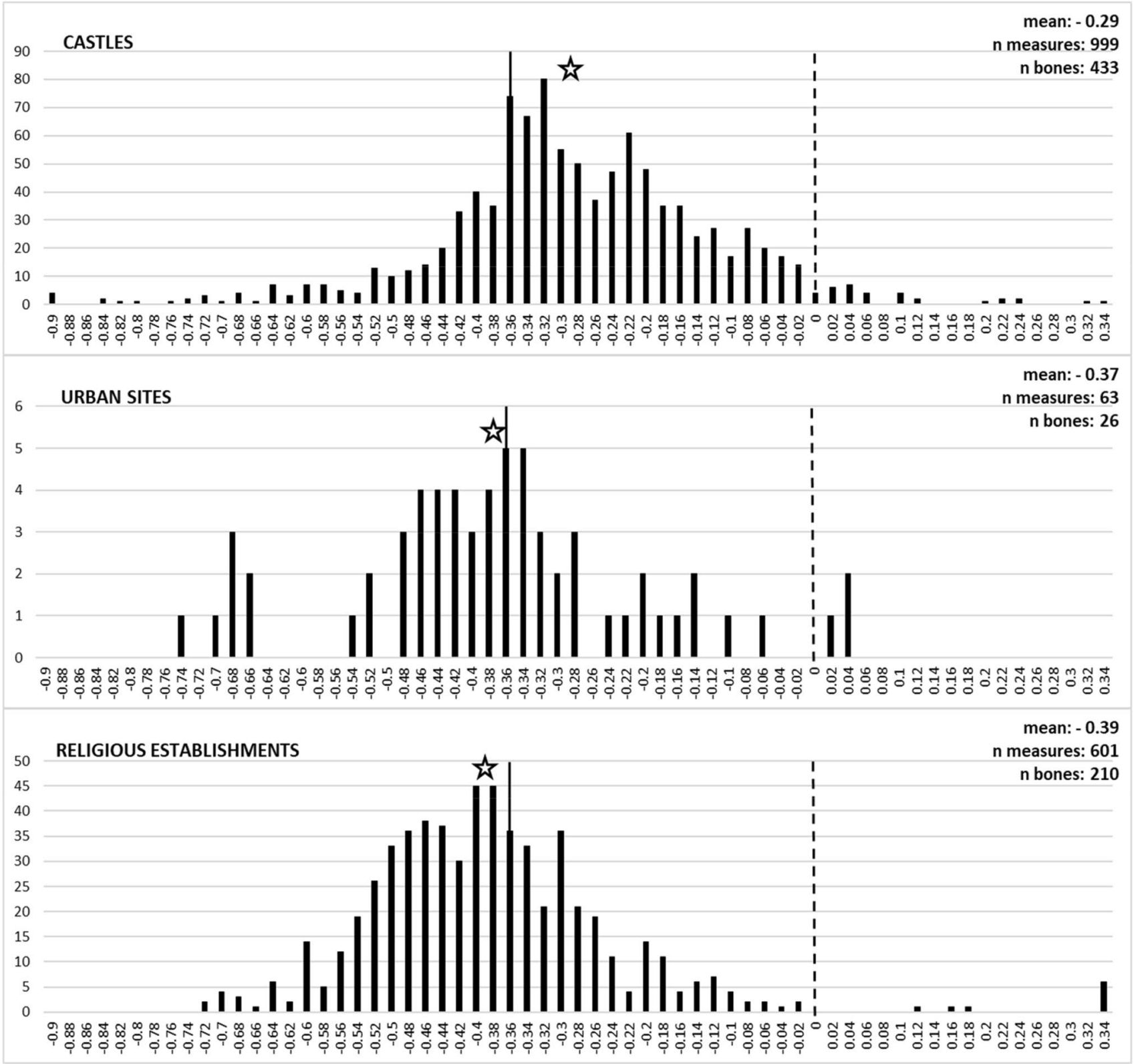

Fig. 17 Distribution of log ratio values for all anatomical elements for pike from 11 to 15 th $\mathrm{c}$. sites. The star indicates the mean, and the full line marker represents a modern pike (origin: unknown) with TL

three religious establishments compared to castles may be a consequence of a demand required from a diet which follows religious precepts (i.e. meat avoidance). Harland et al. (2016) noticed at medieval York how fishing pressure on a specific species can indeed lead to a decrease in the average fish size. This fish demand seems to be also supplemented by the purchase of herring, probably mostly in preserved form, which explains the lower frequency of freshwater fishes in ecclesiastic sites compared to castles. Moreover, herring and of $340 \mathrm{~mm}$ and SL of $300 \mathrm{~mm}$ (mean:-0.36). The standard set of values is represented by the value 0 (TL: $715 \mathrm{~mm}$, SL: $650 \mathrm{~mm}$; modern individual, origin: France)

other small-sized fish, as observed by Van Dam (2009, 324, 328), were ideal food for fasting because larger fish might have been considered particularly desirable, and therefore forbidden and regarded as sinful by certain monastic orders.

The wealthiest establishments owned fishponds and mills and had access to river fisheries; but inhabitants of towns generally relied on food sourced from the countryside or on cheaper, imported, preserved marine fish sold at the market, while the purchase of fresh freshwater fish 


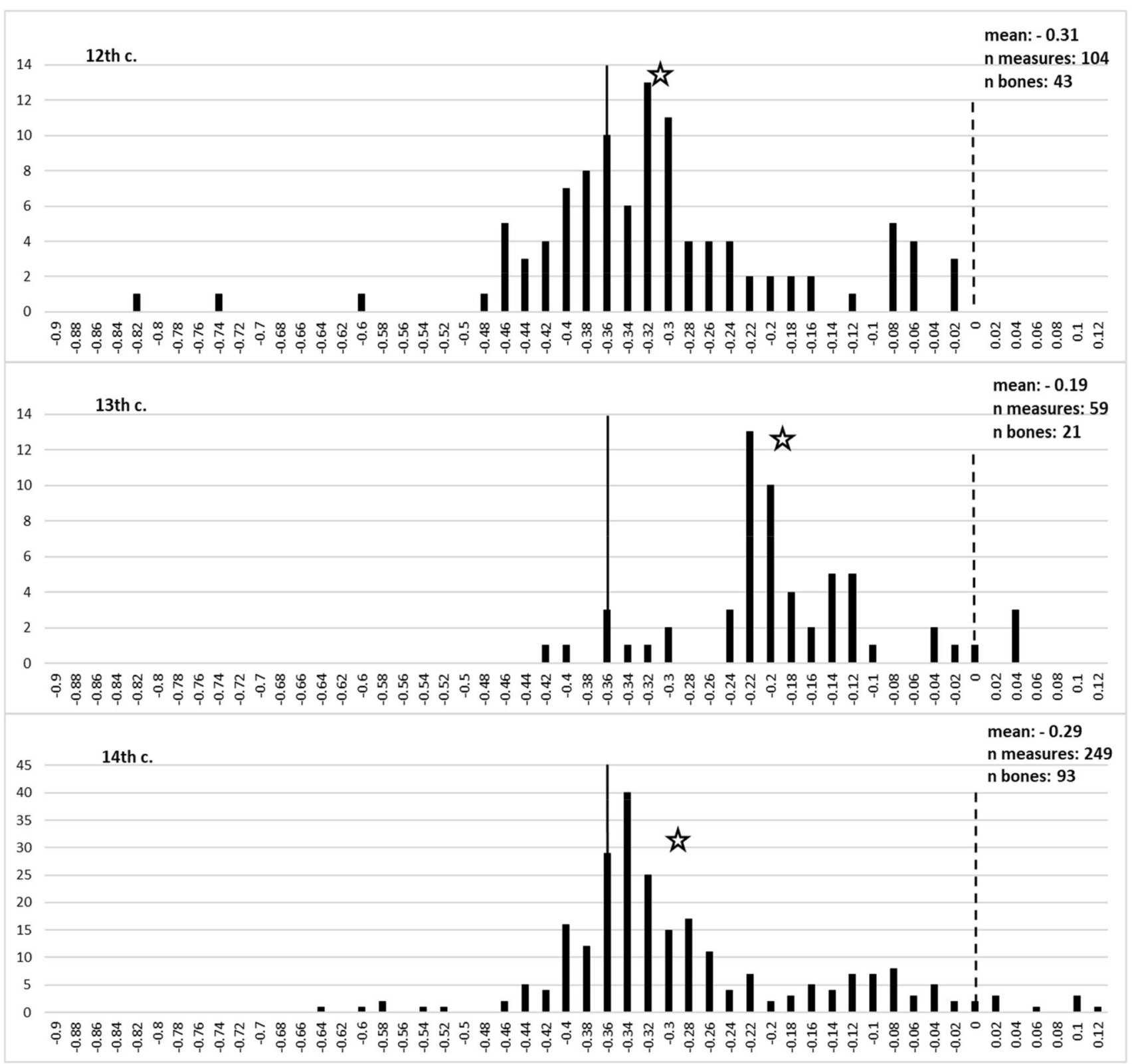

Fig. 18 Distribution of $\log$ ratio values for all anatomical elements for pike by chronology for Windsor Castle. The star indicates the mean, the full line marker represents a modern pike (origin:

was more expensive (Albarella 2005, 140; Van Neer et al. 2009). Reflecting this trend, our urban sites are generally characterised by lower frequencies of highly regarded species. Similarly, in the above-mentioned Belgian review (Van Neer and Ervynck 1994), urban assemblages, dated from the 13 th to 18 th $\mathrm{c}$. $\mathrm{AD}$, were dominated by higher proportions of marine fish, especially Gadiformes, Pleuronectiformes and herring. These higher frequencies were interpreted as the economic limitation of obtaining freshwater fish within unknown) with TL of $340 \mathrm{~mm}$ and SL of $300 \mathrm{~mm}$ (mean:-0.36). The standard set of values is represented by the value 0 (TL: $715 \mathrm{~mm}$, SL: $650 \mathrm{~mm}$; modern individual, origin: France)

urban contexts. Such reduced accessibility resulted from shrinking freshwater habitat due to pollution, infrastructure works which modified the rivers' flow, but also from high taxes placed on fishing from freshwater sources.

The smaller-size fish from urban environments has also been reported in a study by Heinrich (1994), where fish assemblages recovered from an urban context (Höxter 16 th-17th c. AD) were compared with those from two medieval castles, Bodenteich (13th-18th c. AD) and Plesse 


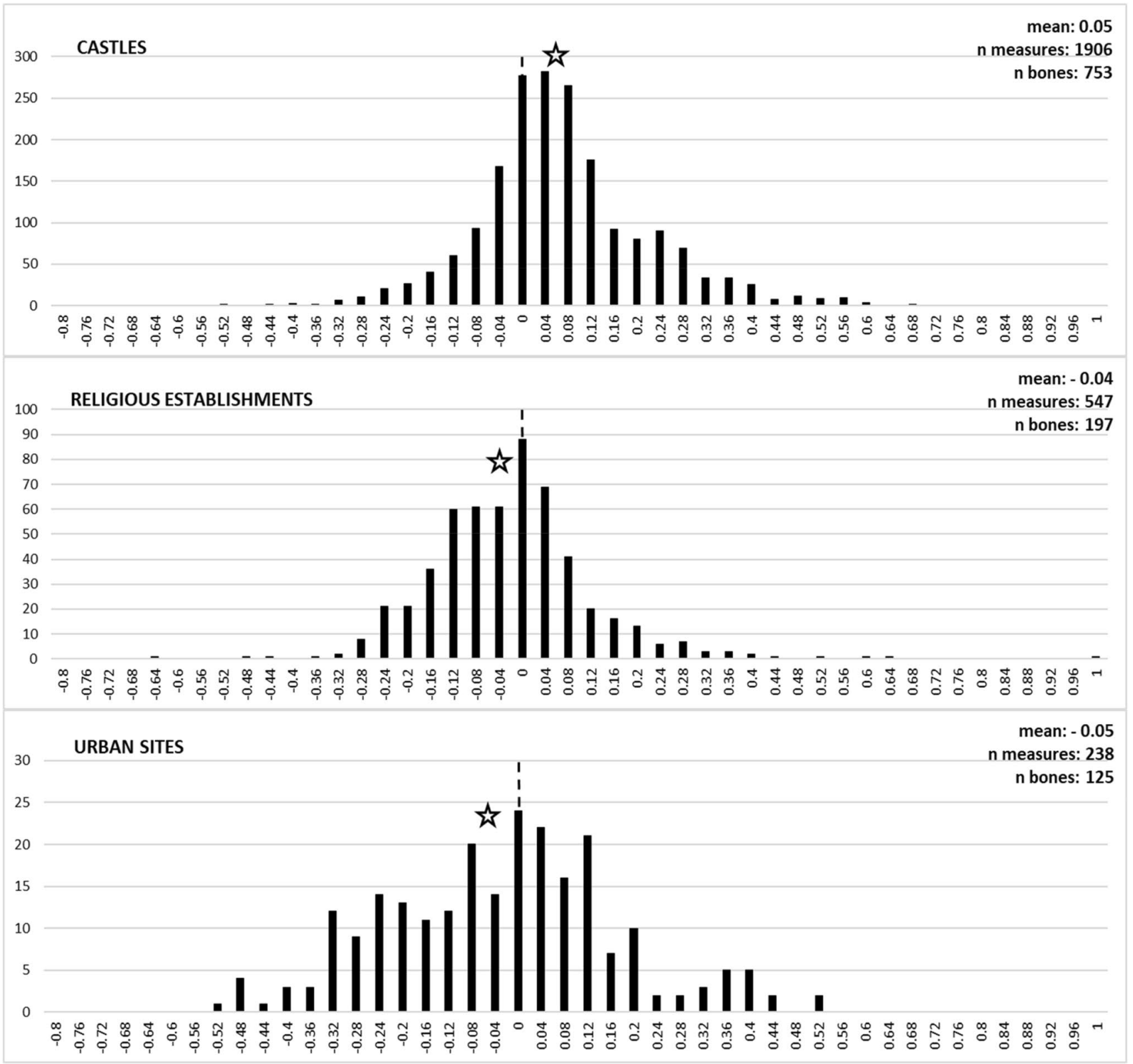

Fig. 19 Distribution of $\log$ ratio values for all anatomical elements for Cyprinidae family from 11 to 15 th c. sites. The star indicates the mean. The standard set of values is represented by the value 0 (Rutilus rutilus, TL: $190 \mathrm{~mm}$, SL: $150 \mathrm{~mm}$; modern individual, origin: Italy)

(15th-17th c. AD), from central-northern Germany. Except for Bodenteich's 17th-18th c. AD material, freshwater species predominated in all three sites; in particular, Cyprinidae (e.g. freshwater bream, roach (Rutilus rutilus), chub (Squalius cephalus), carp (Cyprinus carpio)), perch and pike were the most abundant species. In the urban deposits though, Cyprinidae and other freshwater species were solely either small species (including gudgeon (Gobio gobio), Eurasian minnow (Phoxinus phoxinus)) or small juvenile individuals. Furthermore, the highly regarded carp was missing. These results suggested that the diet of townspeople was largely based on preserved marine fish and small freshwater fish, probably reflecting restrictions on freshwater fisheries. A smaller size of fish within urban environments has also been noticed for medieval and postmedieval Belgian towns, where the decrease in the average size of freshwater fish was suggested as a possible indicator of increasing fishing pressure (Van Neer et al. 2009, 32). Within our urban assemblages, small size may reflect some restriction of fishing rights which was customary in 


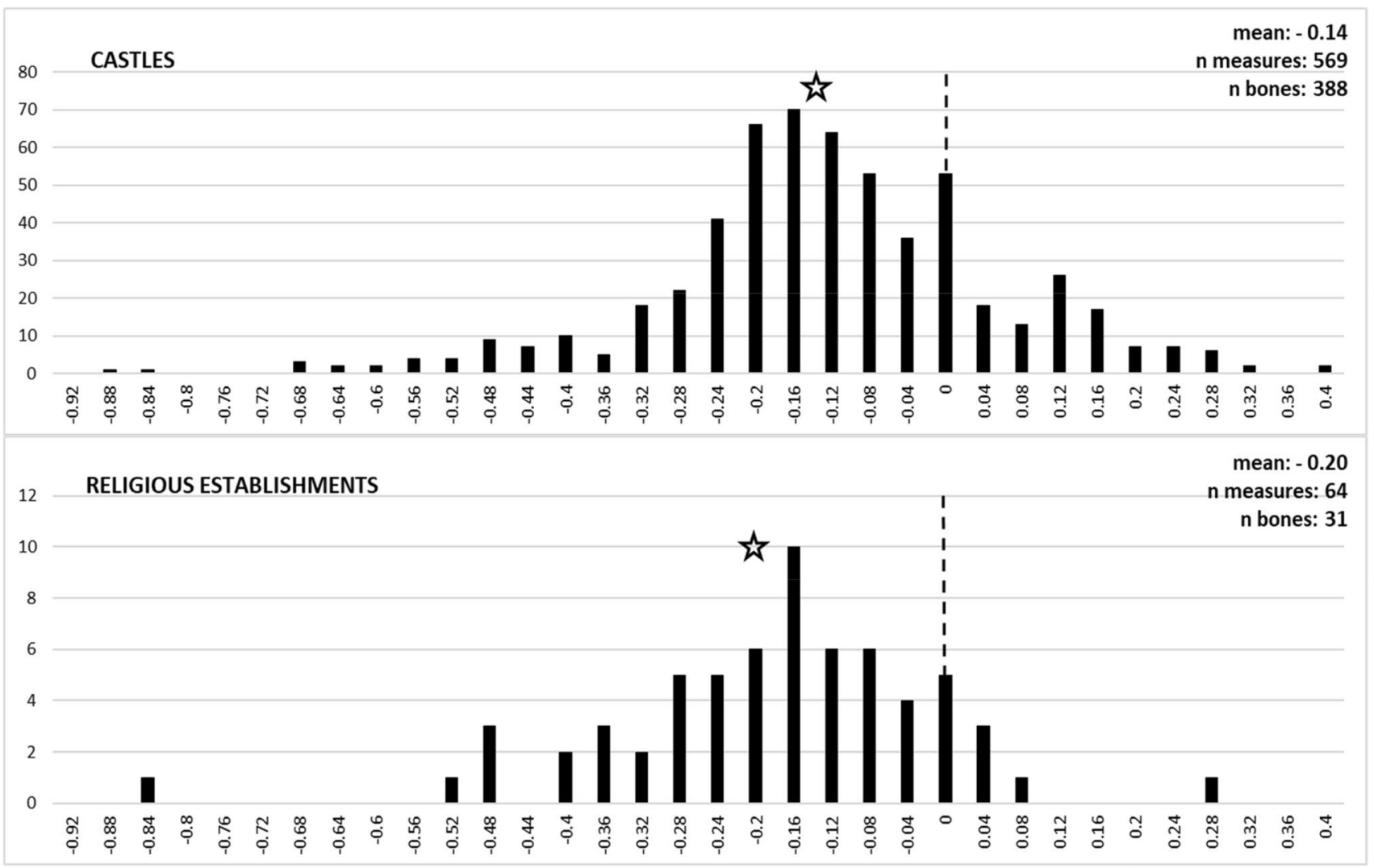

Fig. 20 Distribution of $\log$ ratio values for all anatomical elements for perch from 11 to 15 th $\mathrm{c}$. sites. The star indicates the mean. The standard set of values is represented by the value 0 (TL: $275 \mathrm{~mm}$, SL: $240 \mathrm{~mm}$; modern individual, origin: Italy)

medieval Europe (Hoffmann 1996, 653); these restrictions may have heavily regulated the size of the catch and fishing season, or they may have forbidden fishing in some areas. However, overexploitation could also be an explanation for the small fish size, as freshwater sources may have been pressed to feed large populations.

\section{Conclusion}

In conclusion, it seems that the combination of a high frequency of some key freshwater species (pike, perch, Cyprinidae) and their average large size could be interpreted as indicators of high status within the studied sites. In this sense, the evidence seems to support historical sources attesting a link between freshwater fish and wealthy households. Such evidence can be associated with the occurrence of fishponds, which increased in number in aristocratic households and in religious establishments after the Norman Conquest. Another important indicator of status is a wide range of measurements for these key species coupled with a unimodal distribution, which can be linked to the presence of controlled freshwater environments and the availability of fresh fish throughout the year.

This research has also evaluated the importance of fishponds in the search of indicators of status and how they can affect the nature of fish bone assemblages (in terms of species frequencies and size of the catch). Biometrical investigations have been somewhat underused in archaeoichthyology, typically due to the scarcity of data available; for this research, biometry proved to be a fundamental tool and it represents an innovative approach for exploring archaeological markers of status. The use of the log ratio technique allowed an increased sample size, therefore extending the number and diversity of datasets that could be used to inform about socio-economic aspects of past societies. Further comparisons of taxonomic and biometric composition of fish assemblages from larger sites, with historical and/or archaeological evidence of the occurrence of 


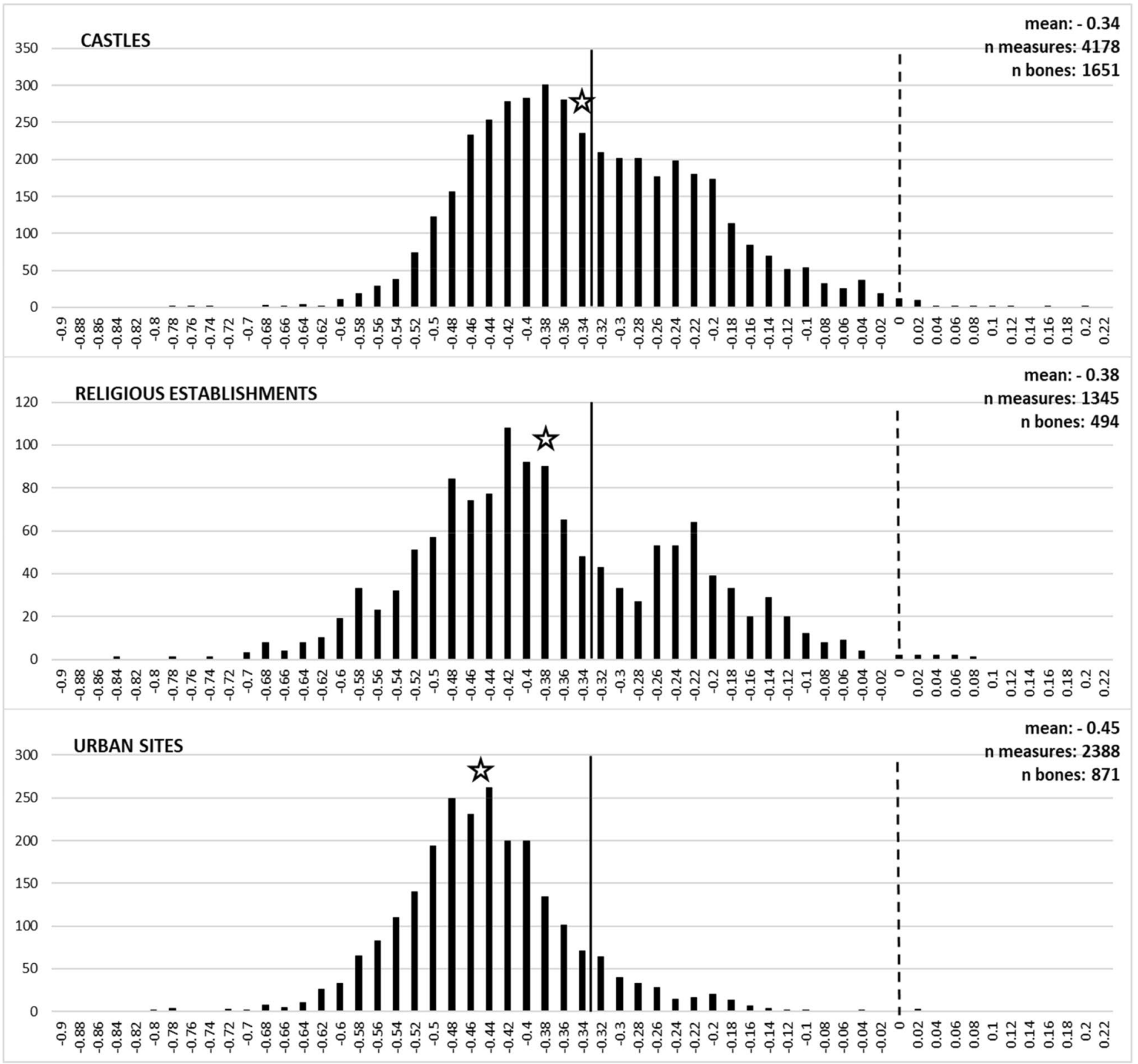

Fig. 21 Distribution of $\log$ ratio values for all anatomical elements for eel from 11 to 15 th c. sites. The star indicates the mean. The full line marker represents a modern eel (origin: unknown) with TL of
$490 \mathrm{~mm}$ and SL of $465 \mathrm{~mm}$ (mean: -0.33). The standard set of values is represented by the value 0 (TL: $960 \mathrm{~mm}$, SL: $940 \mathrm{~mm}$; modern individual, origin: Italy) fishponds, are needed in order to consolidate and further refine these results.

Supplementary Information The online version contains supplementary material available at https://doi.org/10.1007/s12520-021-01373-6.

Acknowledgements I am grateful to Umberto Albarella for supervising this project and to Idoia Grau Sologestoa for the valuable comments on a draft of this paper. The support and supervision of Wim Wouters was essential for the identification of several specimens. I am also indebted to Alison Locker and Sheila Hamilton-Dyer, who tirelessly replied to my many questions and shared their data.

\section{Authors' contributions Not applicable}

Funding This project was funded by a Faculty of Arts and Humanities PhD Scholarship Award granted by the University of Sheffield and by the Arts and Humanities Research Council (grant number AH/L503848/1) through the White Rose College of the Arts and Humanities. 
Data Availability Not applicable

Code Availability Not applicable

\section{Declarations}

Conflicts of interest The author declares no competing interests.

Open Access This article is licensed under a Creative Commons Attribution 4.0 International License, which permits use, sharing, adaptation, distribution and reproduction in any medium or format, as long as you give appropriate credit to the original author(s) and the source, provide a link to the Creative Commons licence, and indicate if changes were made. The images or other third party material in this article are included in the article's Creative Commons licence, unless indicated otherwise in a credit line to the material. If material is not included in the article's Creative Commons licence and your intended use is not permitted by statutory regulation or exceeds the permitted use, you will need to obtain permission directly from the copyright holder. To view a copy of this licence, visit http://creativecommons.org/licenses/by/4.0/.

\section{References}

Albarella U (2005) Meat production and consumption in town and country. In: Giles K, Dyer C (eds) Town and country in the middle ages: contrasts, contacts and interconnections, 1100-1500. Routledge, London, pp 131-148

U Albarella (2007) Companions of our travel: the archaeological evidence of animals in exile S Hartmann Eds Fauna and Flora in the Middle Ages Verlag Peter Lang, Frankfurt an Main Studies of the medieval environment and its impact on the human mind 133154

Albarella U (2019) Review of Animal Bone Evidence from Central England. Research Report Series 61/2019. Historic England, Portsmouth.

Albarella U, Payne S (2005) Neolithic pigs from Durrington Walls, Wiltshire, England: a biometrical database. J Archaeol Sci 32(4):589-599

Ashby SP (2002) The role of zooarchaeology in the interpretation of socioeconomic status: a discussion with reference to Medieval Europe. ARC Report 18(2):37-59

Ayres K, Ingrem C, Light J, Locker A, Mulville J, Serjeantson D (2003) Mammal, bird and fish remains and oysters. In: Hardy A, Dodd A, Keevill GD (eds) Ælfric's Abbey: Excavations at Eynsham Abbey, Oxfordshire, 1989-92. Oxford Archaeological Unit Ltd, Oxford, pp 341-432

Barrett JH, Locker AM, Roberts CM (2004a) 'Dark Age Economics' Revisited: The English Fish Bone Evidence AD 600-1600. Antiquity 78:618-636

Barrett JH, Locker AM, Roberts CM (2004b) The origins of intensive marine fishing in medieval Europe: the English evidence. Proc Royal Soc B 271:2417-2421

Barrett J, Orton D (2016) Cod and herring: the archaeology and history of medieval sea fishing. Oxbow, Oxford

Bond J (2016) The increase of those creatures that are bred and fed in the water fishponds in England and Wales. In: Bonow et al. 2016, pp 157-191.

Bonow M, Olsén H, Svanberg I (2016) Historical Aquaculture in Northern Europe. Elanders, Stockholm.

Borvon A (2019) New data about the consumption of fish from the Alsace Region. France Int J Osteoarchaeol 29(3):407-419
Bullock A (1994) Evidence for fish exploitation from Tudor deposits excavated at Little Pickle, Surrey/England in 1989. In: Heinrich D (1994b), pp 267-274.

Crabtree P (1990) Zooarchaeology and complex societies: some uses of faunal analysis for the study of trade, status, and ethnicity. In: Schiffer MB (ed) Archaeological Method and Theory. University of Arizona Press, Tucson.

Currie CK (1988) Medieval Fishponds in Hampshire. In: Aston M (ed) Medieval Fish, Fisheries and Fishponds in England. B.A.R. British Series 182(ii): 267-89.

Dyer C (1994) Everyday life in Medieval England. The Hambledon Press, London

Ervynck A (1997) Following the rule? Fish and meat consumption in monastic communities in Flanders (Belgium). In: De Boe G, Verhaeghe F (eds) Environment and subsistence in Medieval Europe. Instituut voor het Archeologisch Patrimonium, Zellik, pp 67-81.

Ervynck A, Van Neer W, Hüster-Plogmann H, Schibler J (2003) Beyond Affluence: The Zooarchaeology of Luxury. World Archaeol 34(3):428-441

Galik A, Kunst GK (2004) Dietary habits of a monastic community as indicated by animal bone remains from Early Modern Age in Austria. In: O'Day et al. (2004), pp 224-232

Grau Sologestoa I (2017) Socio-economic status and religious identity in medieval Iberia: The zooarchaeological evidence. Environ Archaeol 22(2):189-199

Harland JF, Jones AKG, Orton DC, Barrett JH (2016) Fishing and Fish Trade in Medieval York: The Zooarchaeological Evidence. In: Barrett JH, Orton DC (2016), pp 172-204

Harvey BF (1993) Living and dying in England 1100-1540: the monastic experience. The Clarendon Press, Oxford

Heinrich D (1994) Fish remains of two medieval castles and of an urban context - a comparison. In: Van Neer W (ed) Fish Exploitation in the Past. Proceedings of the $7^{\text {th }}$ Meeting of the I.C.A.Z. Fish Remains Working Group. Sciences Zoologiques 274. Musée Royal de l'Afrique Central, Tervuren, pp 211-216

Hoffmann RC (1996) Economic Development and Aquatic Ecosystems in Medieval Europe. AHR Report 101:631-669

Hoffman RC (2008) Medieval Europeans and their Aquatic Ecosystems. In: Herrmann B (ed) Beiträge zum Göttinger Umwelthistorischen Kolloquium 2007-2008. Universitätsverlag, Göttingen.

Holmes M (2017) A Review of Animal Bone Evidence from the Sacon to Post Medieval Periods in Southern Britain. Research Report Series 08/2017. Historic England, Portsmouth

Klemettilä H (2012) The Medieval kitchen. Reaktion Books, London, A social history with recipes

Libois RM, Hallet-Libois C (1988) Éléments pour l'identification des restes crâniens des poisons dulçaquicoles de Belgique et du nord de la France. 2. Cypriniformes. In: Desse J, Desse-Berset N (eds) Fiches d'Ostéologie animale pour l'Archéologie. Série A, Poisson 3. Centre de Recherches Archéologiques du CNRS, Juan-les-Pins

Locker A (1994) The Fish Bones from the Fleet Valley, sites VAL 88 and PWB88. Unpublished report for Museum of London Archaeological Service.

Locker A (1995) The Fish Bones. In: Mills P (ed) Excavations at the dorter undercroft, Westminster Abbey. LAMAS 46. Museum of London, London.

Locker A (2000) The role of stored fish in England 900-1750AD; the evidence from historical and archaeological data. $\mathrm{PhD}$ thesis, University of Southampton.

Locker A (2018) Freshwater fish in England. A social and cultural history of coarse fish from prehistory to the present day. Oxbow Books, Oxford.

Meadow RH (1999) The use of size index scaling techniques for research on archaeozoological collections from the Middle East. In: Becker C, Manhart H, Peters J, Schibler J (eds) Historia animalium ex ossibus. Beiträge zur Paläoanatomie, Archäologie, 
Ägyptologie, Ethnologie und Geschichte der Tiermedizin. Verlag Marie Leidorf GmbH, Rahden, pp 285-300

Morales-Muñiz A (2014) Ichthyoarchaeology. In: Smith C (ed) Encyclopaedia of Global Archaeology. Springer, New York, pp 3648-3659

O'Connor T (1989) Deciding priorities with urban bones: York a case study. In: Serjeantson D, Waldorn T (eds) Diet and Crafts in Towns. The evidence of animal remains from the Roman to the Post-Medieval periods. B.A.R. British Series 199, Oxford, pp 189-200

Patrick P (2016) The Obese Medieval Monk: A multidisciplinary study of a stereotype. B.A.R. British Series 590, Oxford

Pigiére F, Boone I, Udrescu M, Van Neer W, Vanpoucke S (2004) Social status as reflected in the food refuse from late medieval sites in Namur. In: O'Day et al. (2004), pp 233-243

Serjeantson D, Woolgar CM (2006) Fish consumption in Medieval England. In: Woolgar CM, Serjeantson D, Waldron T (eds) Food in Medieval England: History and Archaeology. Oxford University Press, Oxford, pp 102-130

Simpson GG, Roe A, Lewtontin RC (1960) Quantitative zoology, revised. Harcourt, Brace and World, New York

Smith P (1995) The fish bone from Launceston Castle, Cornwall. AML Report 56/95. London: Historic Buildings and Monuments Commission for England

Smith P (1997) The Fish Bone. In: Oakley N, Spoerry P (eds) Excavations at Orchard Lane, Huntingdon, 1994. Proceedings of the Cambridge Antiquarian Society LXXXV, the Cambridge Antiquarian Society, Oxford, pp 149

Sykes N (2007) The Norman Conquest: A Zooarchaeological Perspective. B. A. R. International Series 1656, Oxford

Taylor CC (2000) Medieval Ornamental Landscapes Landscapes $1: 38-55$

Tesch F-W (2003) The Eel. Blackwell Science Ltd, Oxford

Thomas KD (1999) World Archaeol 31(1):38-54
Twiss K (2012) The Archaeology of Food and Social Diversity. J Archaeol Res 20(4):357-395

Van Dam PJEM (2009) Fish for feast and fast fish consumption in the Netherlands in the late Middle Ages. In: Sickin L, Abreu-Ferreira D (eds) Beyond the Catch. Fisheries of the North Atlantic, the North Sea and the Baltic, 900-1850. Brill, Boston, pp 309-336

Van der Veen M (2003) When is food a luxury? World Archaeol 34(3):405-427

Van Neer W, Ervynck A (1994) A preliminary survey of fish remains in medieval castle abbeys and towns of Flanders (Belgium). In: Heinrich (1994b), pp 303-308

Van Neer W, Ervynck A (2004) Remains of traded fish in archaeological sites: indicator of status or bulk food? In: O’Day et al. (2004), pp 203-214

Van Neer W, Ervynck A, Fuller B, Degryse P, Wouters W (2009) Freshwater fisheries in Belgium during medieval and post-medieval times: looking for markers of overfishing and pollution. In: Makowiecki D (ed) Fishes - Culture - Environment through Archaeoichthyology, Ethnography \& History. Proceedings of the 15th Meeting of the I.C.A.Z. Fish Remains Working Group. Poland, Poznan \& Torun, pp 31-34

Woolgar CM (2000) "Take this penance now, and afterwards the fare will improve": seafood and late medieval diet. In: Starkey D, Reid C, Ashcroft N (eds) England's Sea Fisheries: the Commercial Sea Fisheries of England and Wales since 1300. Chatham, Poznan \& Torun, pp 36-44

Woolgar CM (2016) The culture of food in England 1200-1500. Yale University Press, Padstow

Publisher's note Springer Nature remains neutral with regard to jurisdictional claims in published maps and institutional affiliations. 